\title{
An Awakening to Political Awareness through Children's Literature
}

\author{
Hilary Pollack \\ University of Wisconsin, River Falls \\ United States
}

\begin{abstract}
When children are introduced to children's literature, the innocence of childhood inevitably gives way to an awakening of awareness and the shaping of values and ideas. Historically, children's literature perpetuated the status quo and was respectful of traditional values. More contemporary authors, however, have presented themes which question political structures and address environmental issues. Respected authors such as Dr. Seuss, Leo Lionni, Marcus Phister, Judi Barrett, and Doreen Cronin integrate social commentary into children's books and present them as a vehicle for exploration of ideas and concepts. These authors examine themes such as war and peace, socialism, environmental disaster, and gender identity in the context of engaging stories for children. As a response to the perceived liberal views that characterize many of these books, conservative examples have also emerged to present other points of view.
\end{abstract}

\section{Introduction}

"There is no more powerful agent of change than a book with a political agenda." --Dr. Seuss

"If we are to teach real peace in this world ... we shall have to begin with the children." -Gandhi

The preservation of the innocence of childhood, although a well-respected construct, inevitably unravels as children are exposed to the world. Through children's literature, many children are introduced to larger world views than they might experience in the sanctuary of their families. While some may regret the loss of innocence that inexorably accompanies the acquisition of literacy skills, many children's authors have produced remarkable literature that enlightens, informs, and leads to an awakening of political awareness, while preserving the delight that is inherent in childhood.

\section{Literature Review}

Traditionally children's literature has been presented as a genre supporting the status quo, but affirming possibilities for upward mobility. Early examples such as Horatio Alger's stories of Ragged Dick focus on the ability of everyone to get ahead in life if they are tenacious and persistent. Tootle, by Gertrude Crampton, affirms the importance of staying on the tracks and not being led astray by life's temptations [28]. These examples communicate the message that if you work hard and follow the rules, you will be rewarded. Many classic and contemporary children's books perpetuate this idea with benign, well-behaved children, perhaps a little naughty, but generally recognizing the wisdom of their elders. Although there are certainly disobedient characters portrayed in children's books (Max in Where the Wild Things Are, Fudge in Superfudge, Lily in Lily's Purple Plastic Purse, Thomas in Thomas' Snowsuit, just to mention a few), they are generally led toward an assimilation into the culture without actually compromising their childish antics. Well-known characters like Alexander (Alexander and the Terrible, Horrible, No Good, Very Bad Day), Wendell and Sophie (A Weekend With Wendell), Henry and Mudge (Puddle Trouble), and even Pierre with his "I don't care" attitude (Pierre) defy authority and express some rebellious attitudes, but ultimately defer to the social and political mores that define their lives and continue the "happily ever after" mode that defines fairy tales and dominates much of children's literature [28].

\section{Discussion}

The progressive leanings that are often reflected in children's literature spring from a hope that the innocence of childhood is characterized by a belief in social justice which can logically lead to the questioning of authority. Rarely, however, does the reader get a sense of significant change occurring because of this questioning. 
Traditionally, "a set of shared understandings and a feeling of cooperation between those of varying political beliefs seems to have distinguished the children's literature field from many other realms of cultural production" [27]. However, subtle and explicit political messages do creep into children's literature. Although there has been a strident outcry regarding some of the political themes in children's book (e.g.: Are You There God? It's Me, Margaret, and the Harry Potter series), generally there is less attention to the political suggestions in children's books than in other arenas of cultural literacy, which might have a broader base. In fact, Mickenberg observes "most children's books tend to receive very little attention, critical or otherwise" [27]. Although some of the most famous children's writers of the twentieth century are men (Dr. Seuss, E. B. White, Roald Dahl), the field is dominated by women in terms of writing, editing, and dissemination through librarians and teachers. This fact has contributed to the devaluation of the political messages in children's literature and also the lack of attention when controversial themes do emerge [26].

One of the characteristics of the political nuances in children's literature is that while they may be critical of past or present injustices, they generally are respectful of the American way of life and governmental structure. That society can be reconstructed to make things better is the implicit message in Dr. Seuss's The Lorax. Although the devastating industry fostered by the greedy Once-ler results in the demise of the Truffula trees, the flight of the Swomee-Swans, and the exodus of the Brown Bar-ba-loots and Humming-Fish, that scenario is not irreversible. Dr. Seuss acknowledged the possibility of hope when he removed the line "I hear things are just as bad up in Lake Erie" from the book more than fourteen years after it was published. His response to the two research associates from the Ohio Sea Grant Program who wrote to him about the clean-up of Lake Erie reflects the glimmer of optimism that the Once-ler expresses at the end of The Lorax [30]. "Now that you're here," the Once-ler proclaims to the little boy ". . . the Lorax and all of his friends may come back" [40].

Dr. Seuss is well-recognized for the political causes that he embraces in his books. The wacky characters and imaginative language of The Sneetches will stay with young and not-so-young readers long after they put the book down, as will the messages that bellies with stars do not define a creature's worth and pointless prejudice and discrimination do not benefit the privileged class [39]. Seuss's most explicit political message comes in The Butter Battle Book, a clear commentary on the arms escalation of the cold war. Battle lines are drawn as Yooks eat bread with the butter side up and Zooks eat with the butter side down. The "boys in the back room," Seussian think-tanks, scurry to invent new, more powerful weapons [41]. The meaningless prejudice is reminiscent of The Sneetches, but there is little hope for a happy resolution in The Butter Battle Book. The book ends with both sides ready to drop their "big-boy boomeroo," and even the most innocent readers can sense the reflection of despondence that accompanied the nuclear proliferation that haunted the last half of the twentieth century. But no one dies and nothing explodes (although it seems imminent), so perhaps children can attach their youthful optimism to the possibility of disarmament and peace.

In Cloudy with a Chance of Meatballs, author Judi Barrett revisits the theme of environmental disaster suggested in The Lorax as drastic climate change prompts the residents of the little town of Chewandswallow to evacuate and seek a new habitat. Once again the theme of hope emerges as the townspeople valiantly convert excessive, unwanted food that falls from the sky into boats and triumph over an inhospitable climate [4]. This behavior, the embodiment of childish hope, exemplifies the model of individuals actively working against catastrophe and toward the realization of a better world, one of the quintessential tenets of American democracy.

Leo Lionni gently reinforces his political messages with anthropomorphic mice and fish whose animal experiences are analogous to human problems and solutions. Swimmy evades predators by joining together with other small fish to chase the big fish away [23]. Frederick astounds his hard-working mouse family by demonstrating that there is a need for poets in society [22]. And the word bug and the caterpillar in The Alphabet Tree convince the disparate letters that not only is there strength in unity, but they also have the responsibility to spread the message of peace on earth, to take it to the president [24]. The presentation of these bold ideas is mitigated by sweet characters framed in their habitats of impressionistic water colors and an economy of language that simplifies the concepts so that they can be understood and internalized by juvenile readers.

In another underwater tale, The Rainbow Fish, Marcus Phister presents a clear case for socialism, according to some critics [1]. The Rainbow Fish takes inordinate pride in all of his sparkling silver scales and is initially appalled at the idea that he should share his scales with the other fish. A wise octopus, however, teaches him that unhappiness is the price of his vanity, and the selfish individualism of Rainbow Fish yields to magnanimous giving, creating an equitable world where all the fish in the 
ocean share the glittery scales. Sharing of assets is clearly valued above personal beauty and ownership as Rainbow Fish realizes that "the more he gave away, the more delighted he became" [33].

Strength in unity also is suggested in Click, Clack, Moo, Cows That Type, by Doreen Cronin [10]. Farmer Brown's cows find a typewriter and politely ask for better conditions (electric blankets) in the barn. When Brown refuses, they go on strike and refuse to give milk. The humor of cows typing and a duck serving as mediator contrasts with the very authentic analogy that Cronin presents of labor unions and intransigent bosses. There are several informative books for children about labor unions and biographies of labor organizers such as Cesar Chavez and Mother Jones, but Click, Clack, Moo has a unique appeal that may send kindergartners to corners of the playground to initiate collective bargaining for more recess or colorful markers.

Gender identity is a theme often explored in adolescent literature, and ideas also trickle down to younger readers. While many may not consider this a political issue, politicians seem inordinately interested in "don't ask, don't tell" policies related to the military and the legality of same-sex marriages, thereby transforming private issues into public fodder. Children's books that consider issues related to gender and sexual orientation are prime targets for censorship and often are fuel for the fire of fundamental religious leaders, politicians, and selfappointed protectors of the moral fabric of society [13].

In William's Doll Charlotte Zolotow defies generally accepted values by suggesting that it is okay for little boys to play with dolls, to cuddle them, feed them, put them to bed, and wake up with them in the morning. William's brother and his friend make fun of him, his father attempts to distract him with "manly" toys, but his wise grandmother understands that having a doll does not make William a sissy; rather it might contribute to helping him to become a good father eventually [52]. First published in 1972, William's Doll offers a ground-breaking perspective on gender stereotypes, and subsequent children's books explore this theme even more explicitly and raise many pertinent questions. Does reading a book about a duck that prefers baking to boxing and puppet shows to football (The Sissy Duckling) encourage children to explore that life-style? Do examples of homosexual relationships in nature (And Tango Makes Three) lead children toward similar choices? Is the fact that one of Heather's moms was artificially inseminated (Heather Has Two Mommies) a threat to conventional families? Although there is no evidence to suggest such a connection, these books and others with similar themes are rarely found in school libraries or on the shelves of elementary classrooms [12] [32] [35].

The depiction of roles of males and females in society is an aspect of children's literature that can easily lead to gender stereotyping. In many examples, protagonists follow traditional roles that ring true with children. Strong character development, however, can help to defy stereotypes as little boys can play with trucks and little girls can love babies (The Pain and the Great One) but their personalities emerge independent of the stereotypical behavior that they might display [7]. A somewhat generic tree, identified clearly as a female, however, can suggest some unpleasant generalizations about male/female relationships. Although The Giving Tree has long been accepted as a heart-warming story about the joy and satisfaction of giving, it is clear that the tree (personified as a female) is doing all of the giving and the boy is doing all of the taking [44]. The childlike appeal of the story is compromised as close scrutiny reveals a strong theme of the subjugation of females by males.

Novels that examine the cold war and the fear of communism and nuclear war that dominated the political arena of the $1950 \mathrm{~s}$ are experiencing a resurgence in this century. In Rex Zero and the End of the World, characters scoff at the concept of "a war to end all wars" [48]. The war veterans and survivors who populate these novels communicate cynicism and bewilderment that their previous agony and sacrifice may have done little to improve the condition of the world. The horror of the memories of World War II veterans in David Almond's FireEaters, the bullets and the bayonets and the bombs, are revisited in the context of the Cuban missile crisis and the impending sense of disaster that characterized that era [2]. Historical fiction may be based on actual events, but is certainly influenced by the author's interpretation of those events and subsequent consequences.

Children's books have emerged to address most of the major wars that have plagued modern civilization. In addition to the historical background that these books provide, attention is often given to the emotional impact these wars have on the lives and minds of children. Many books dealing with children's experiences during World War II and the Holocaust (Number the Stars, The Devil's Arithmetic, Lily's Crossing, and The Boy in the Striped Pajamas, for example) have been written to provide a variety of perspectives to this chapter in history. More recently, authors of children's books have considered the conflict in the middle-east, writing books such as A Little Piece of Ground, a poignant view of a young Palestinian boy's experience in the occupied West Bank and his efforts to survive the Israeli occupation 
[20]. Author Kathleen Laird explains, “The imagination is the only place they [children] can test themselves against reality, and think: 'What would I do if I was in that situation? Would I be brave enough? Would I be loving and caring enough? Would I make that decision?' So one of the values of literature is that we give children the chance to step into the shoes of people they'd never otherwise meet" [34].

Almost all of the children's books referenced in this paper present what most would consider a liberal or left-wing interpretation of the themes that characterize children's stories. Although the impact of children's literature as a vehicle for social and political change has been questioned (see above), some object to this perceived bias in reading materials that are available to children. In 2005 Katharine DeBrecht launched her Help! Mom! series to present conservative ideals and teach traditional values. In the first book of the series, Help! Mom! There are liberals under the bed! two young boys open a lemonade stand to earn money for a swing set, only to be plagued by liberal concepts such as taxes, separation of church and state, and good nutrition. They are encouraged by their parents to work hard so that they can feel better about themselves, a seemingly neutral concept, until it is contrasted with liberal social welfare programs. If the message isn't obvious, the picture of Ronald Reagan hanging on the wall clarifies the political lines that are being drawn [11]. The mission of the newly formed World Ahead Publishing Company is quite explicit: "to provide books for families who have traditional values . . . who want to have books as a tool to pass those values to their children" [1]. The message that emerges from DeBrecht's series is clear and explicit, partisan and politically-charged. The Help! Mom! series infuses bedtime stories with new possibilities for preaching values and espousing political causes.

Mickenburg and Nel make a strong case that children's literature "has been and continues to be an important vehicle for ideas that challenge the status quo and promote social justice, environmental stewardship, and greater acceptance of differences" [29]. They emphasize the importance of literature as an avenue to develop critical thinking so that children can be agents of change and work to build a better world, regardless of their political views [29]. As Dr. Seuss states clearly in The Lorax: "UNLESS someone like you cares a whole awful lot, / Nothing is going to get better. It's not" [40].

\section{The Voices of Children}

Children's responses to the messages in these books are varied, but reflect an appreciation for the issues. Elementary curricula that focus on self-esteem and bullying highlight values that are promoted in some of the books and can help to lead children to thoughtful observations. Recent conversations with the fourth graders about The Sneetches reveal an awareness of the connections of the book to contemporary political and social issues, as well as the connections to their own lives. Gracie observed that "star bellies are white people and they have more privileges. I think this book is kind of talking about race." Alex concludes, however, that "it doesn't matter what you look like. Who cares if you have a star on your belly?" Josie seems to internalize Dr. Seuss' philosophy when she states "don't let anyone think that you are worth less than anyone else. Everyone is special!" Discussions with fifth graders about Yertle the Turtle also highlight the Seussian conclusion from Mack, the smallest of turtles that "I know up on top you are seeing great sights, but down on the bottom we, too, should have rights!" [43]. Julia stated definitively, "Don't let anyone else tell you what to do. If it is putting you in danger or if you know something is wrong, don't let someone bully you!" Anders reflected that "if you're selfish, there are consequences."

Third graders responded thoughtfully to the message of The Alphabet Tree, proposing that Lionni's tale of letters bonding together to bring a message of peace to the president imply, according to Riley, that "he [the president] can tell everyone that everyone should have peace and harmony." Libbie defined peace as "being calm and helping out the earth" and Andrew added "no conflict and everyone gets along." Discussions among these children about The Butter Battle Book focused on Mark's conclusion: "Don't fight over something dumb!" Julie noted that the warring factions in the book "were trying to stand up for their side and make the other side hurt." The children agreed that "each side was trying to protect themselves and their values, but they didn't care if people got hurt, and that's not okay."

Fifth graders had limited reactions to Help! Mom! There are liberals under the bed! Most of them did not recognize the caricatures of Hillary Clinton, Ronald Reagan, and Teddy Kennedy, or the allusions to social welfare programs. They did, however, appreciate the value of earning your own money to buy things, and Lisa echoed the sentiments of the children in the book when she said "it feels good to earn money and buy something you want." Brent 
wondered if "kids could really make enough money to buy a swing set."

\section{Conclusion}

Educators from Alfie Kohn to William Bennett, on both sides of the political aisle, have spoken of the impossibility of a values-neutral education. Clearly, the books that parents and teachers select for children convey values and attitudes that are transmitted to children. The challenge is to avoid the lure of children's literature as a source of didactic propaganda or indoctrination and use the ideas presented as a vehicle for critical thought, reflection, and analytical decision making. Ultimately, children will patch together ideas from what they read and learn to design their individual values and political path. As Dr. Seuss reminded us in Oh the Places You'll Go:

You have brains in your head, you have feet in your shoes.

You can steer yourself in any direction you choose.

You're on your own and you know what you know.

You are the guy who'll decide where to go. [39]

\section{References}

[1] Abate, M. (2009). "One State, Two State, Red State, Blue State." The Lion and the Unicorn, Volume 33. John Hopkins University Press.

[2] Almond, D. (2003). The fire eaters. New York: Random House.

[3] Baker, D. (2007). "Why is the cold war hot?" Hornbook, 83 no 6 655-60.

[4] Barrett, J (1978). Cloudy with a chance of meatballs. New York: Atheneum Books for Young Readers.

[5] Blume, J. (1970). Are you there, God, it's me Margaret? New York: Yearling.

[6] Blume, J. (1980). Superfudge. New York: Dutton's Children's Books.

[7] Blume, J. (1974). The pain and the great one. New York: Yearling.

[8] Boyne, J. (2006). The boy in the striped pajamas. New York: Random House Children's Books.

[9] Crampton, G. (1945). Tootle. New York: Simon and Schuster.
[10] Cronin, D. (2000). Click, clack, moo, cows that type. New York: Atheneum Books for Young Readers.

[11] DeBrecht, K. (2005). Help! Mom! There are liberals under my bed! California: World Ahead.

[12] Fierstein, H. (2002). The sissy duckling. New York: Aladdin Paperbacks.

[13] Gaard, G. (1993). "Ecofeminism and native American cultures." In Ecofeminism: women, animals, nature. edited by Greta Gaard. Philadelphia: Temple University Press.

[14] Giff, P. R, (1997). New York: Delacorte Press.

[15] Henkes, K. (1996). Lily's purple plastic purse. New York: Greenwillow Books.

[16] Henkes, K. (1986). A weekend with Wendell. New York: Mulberry Books.

[17] Kohl., H (1995). Should we burn Babar? New York: The New Press.

[18] Kohn, A. (1997). How not to teach values. Phi Delta Kappan Volume 9, www.alfiekohn.org/teaching.

[19] Kronin, D. (2000). Click, clack, moo, cows that type. New York: Simon and Schuster

[20] Laird, E. (2006), A little piece of ground. New York: Haymarket Books.

[21] Lionni, L. (1959). Little blue and little yellow. New York: Harper Collins.

[22] Lionni, L. (1967). Frederick New York: Pantheon Books.

[23] Lionni, L. (1963). Swimmy. New York: Pantheon Books.

[24] Lionni, L. (1968). The alphabet tree. New York: Random House.

[25] Lowry, Lois. (1989). Number the stars. New York: Houghton Mifflin.

[26] McClure, A. (1995). "Censorship of Children's Books.'In Battling Dragons, edited by Susan Lehr. New Hampshire: Heinemann. pp 3-30.

[27] Mickenberg, J. (2006). Learning from the Left: Children's Literature, the Cold War, and Radical Politics in the United States. New York: Oxford University Press.

[28] Mickenberg, J. and Nel, P. (2008). Tales for Little Rebels. New York: New York University Press.

[29] Mickenberg. J. and Nel P. (2011). "Radical Children's Literature Now!" Children's Literature Association Quarterly 36.4 (2011): 445-473. 
[30] Morgan, J. (1995). Dr. Seuss \& Mr. Geisel: a biography. New York: Random House.

[31] Munsch, R. (1985). Thomas' snowsuit. Toronto: Annick Press Ltd.

[32] Newman, L. (1989). Heather has two mommies. New York: Alyson Books.

[33] Phister, M. (1992). The rainbow fish. New York: North-South Books.

[34] MacSween,, R. "Children in conflict: the significance of children's literature in relation to war An interview with Elizabeth Laird" in Plaistow, J. and Hillel, M. (ed). (2010). Sands of Time : Children's LiteratureCulture, Politics and IdentityGreat Britain: University Of Hertfordshire Press.

[35] Richardson, J. and Parnell, P. (2005). And Tango makes three. New York: Simon and Schuster

[36] Rylant, C. (1987). Henry and Mudge in puddle trouble. New York: Simon and Schuster.

[37] Sendak, M. (1962). Pierre. New York: Harper Collins.

[38] Sendak, M. (1963). Where the wild things are. New York: Harper Collins.

[39] Seuss, D. (1961). The sneetches and other stories. New York: Random House.

[40] Seuss, D. (1971). The Lorax. New York: Random House.

[41] Seuss, D. (1984). The butter battle book. New York: Random House.

[42] Seuss, D. (1990). Oh the places you'll go. New York: Random House.

[43] Seuss, D. (1958). Yertle the turtle. New York: Random House.

[44] Silverstein, S. (1964). The giving tree. New York: Harper and Row.

[45] Taxel, J. (1995). Cultural Politics and Writing for Young People. In Battling Dragons, edited by Susan Lehr. New Hampshire: Heinemann. pp 155-69.

[46] Taylor, A. (2010) "Troubling childhood innocence." Australasian Journal of Early Childhood v. 35 no. 1 (March 2010) p. 48-57.

[47] Viorst, J. (1972). Alexander and the terrible, horrible, no good, very bad day. New York: Scholastic.

[48] Wynne-Jones, T.(2007). Rex Zero and the end of the world. New York: Farrar, Straus and Giroux
[49] Yolen, J. (1988). The devil's arithmetic. New York: Viking Penguin.

[50] Zipes, J.(2008) "The twists and turns of radical children's literature." In Tales for Little Rebels. edited by Julia Mickenberg and Phillip Nel. New York University Press: New York.

[51] Zitzer, C. (2009). "Indians, Ingalls, Infirmity, and Inquiry: Exploring the Power of Children's Literature to Shape Perspectives of the World Around Us."Language Arts, Volume 86. California: Professional Books.

[52] Zolotow, C. (1972). William's doll. New York: Harper Trophy Books. 